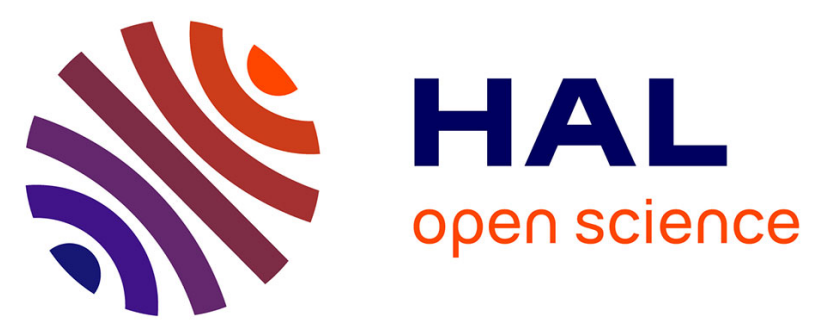

\title{
Biochemical effects of nonyphenol polyethoxylate adjuvant, Diquat herbicide and their mixture on the three-spined stickleback (Gasterosteus aculeatus L.)
}

Wilfried Sanchez, Olivier Palluel, Laurent Lagadic, Sélim Aït-Aïssa, Jean Marc Porcher

\section{To cite this version:}

Wilfried Sanchez, Olivier Palluel, Laurent Lagadic, Sélim Aït-Aïssa, Jean Marc Porcher. Biochemical effects of nonyphenol polyethoxylate adjuvant, Diquat herbicide and their mixture on the three-spined stickleback (Gasterosteus aculeatus L.). Marine Environmental Research, 2006, 62, suppl. 1, pp.S29S33. 10.1016/j.marenvres.2006.04.028 . hal-00020436

\section{HAL Id: hal-00020436 https://hal.science/hal-00020436}

Submitted on 10 Mar 2006

HAL is a multi-disciplinary open access archive for the deposit and dissemination of scientific research documents, whether they are published or not. The documents may come from teaching and research institutions in France or abroad, or from public or private research centers.
L'archive ouverte pluridisciplinaire HAL, est destinée au dépôt et à la diffusion de documents scientifiques de niveau recherche, publiés ou non, émanant des établissements d'enseignement et de recherche français ou étrangers, des laboratoires publics ou privés. 
Biochemical effects of nonylphenol polyethoxylate adjuvant, Diquat herbicide and their mixture on the three-spined stickleback (Gasterosteus aculeatus L.)

W. Sanchez ${ }^{\mathrm{a},}$, O. Palluel ${ }^{\mathrm{a}}$, L. Lagadic ${ }^{\mathrm{b}}$, S. Aït-Aïssa ${ }^{\mathrm{a}}$, J.-M. Porcher $^{\mathrm{a}}$

${ }^{\text {a }}$ National Institute of Industrial Environment and Risk (INERIS), Ecotoxicological risk assessment unit, BP 2, F-60550 Verneuil en Halatte, France

${ }^{\mathrm{b}}$ National Institute of Agronomic Research (INRA), Ecotoxicology and Quality of Aquatic Environments, 65 rue de Saint Brieuc, CS 84215, F-35440 Rennes cedex, France

\footnotetext{
* Corresponding author. Tel. : +33 344556942 ; fax : +33 344556767

E-mail address : wilfried.sanchez-Etudiant@ineris.fr (W. Sanchez)
} 


\begin{abstract}
This study examined the response of 7-ethoxyresorufine-O-deethylase (EROD), glutathioneS-transferase (GST), glutathione peroxidase (GPx), glutathione content (GSH), level of thiobarbituric acid reactive compounds (TBARS) and circulating vitellogenin, in three-spined sticklebacks after 21 days of exposure to Diquat herbicide, commercial nonylphenol polyethoxylate (NPEO) adjuvant and mixture between Diquat and adjuvant. The results showed that adjuvant exerted more important oxidative effects than Diquat and that mixture effects were unlike to single additivity. This study argues for ecotoxicological risk assessment of adjuvants and mixtures of adjuvants and pesticides.
\end{abstract}

Keywords : nonylphenol polyethoxylate, herbicide, oxidative stress, biotransformation enzymes, vitellogenin, three-spined stickleback 
To increase agricultural treatment efficiency, pesticides are frequently used in combination with adjuvants to improve foliar coverage and leaf absorption. Recently, Xie, Thrippleton, Irwin, Siemering, Mekebri, Crane et al. (2005) showed greater than additive effects on vitellogenin synthesis between pesticides and NPEO adjuvant. However, there is still much to be done to understand the underlying mechanisms in the case of mixtures. This study was performed to examine biochemical biomarker responses to NPEO-containing adjuvant and its combination with an herbicide, in three-spined stickleback.

The adjuvant is Agra190 $^{\circledR}$, a commercial non-ionic surfactant including NPEO and widely employed as a tank-mix adjuvant. Nonylphenol and mono- and diethoxylated derivatives are recognized as weak estrogenic endocrine disruptors in aquatic organisms (Schwaiger, Mallow, Ferling, Knoerr, Braunbeck, Kalbfus, et al., 2002) but little is known about the effects of other ethoxylated derivatives of nonylphenol on aquatic wildlife. The associated herbicide is Diquat dibromide (6,7-dihydrodipyrido[1,2-a:2', $1^{\prime}$-c]pyrazinediium), a quaternary ammonium herbicide employed for potatoes and bean weeding and as aquatic herbicide in many countries. The action of Diquat is based on reactive oxygen species production that can also impair biological molecules of aquatic organisms.

According to the known mode of action of Diquat, we studied biomarkers that were related to both oxidative stress (GPx, GSH and TBARS) and oxidative metabolism of xenobiotics (EROD and GST) in the liver. In addition, because degradation products of NPEO are recognised as weak estrogenic, we also measured plasmatic vitellogenin as an indicator of estrogenic response.

Male and female adult sticklebacks were maintained two weeks at $13 \pm 0.5^{\circ} \mathrm{C}$ under $8 / 16$ (Light/Dark) photoperiod. 10 fish per condition were waterborne exposed, in semi-static conditions with complete water renewal and food supply every other day, (1) to environmental (22 and $44 \mu \mathrm{g} / \mathrm{L})$ and sublethal (222 and $444 \mu \mathrm{g} / \mathrm{L})$ Diquat concentrations, (2) 
to Agra190 alone at $50,100,500$ and $1000 \mu \mathrm{g} / \mathrm{L}$ according to the $1: 2.25$ ratio (Diquat:Agra190 ${ }^{\circledR}$ ) advised by the supplier, and (3) to Diquat/Agral90 combinations at concentrations of $22: 50,44: 100,222: 500$ and 444:1000 $\mu \mathrm{g} / \mathrm{L}$ respectively. After 21 days, livers were dissected and homogenized in phosphate buffer supplemented with glycerol and protease inhibitor. The post-mitochondrial fraction was used for biochemical assays according to methods described by Sanchez, Palluel, Meunier, Coquery, Porcher, \& Aït-Aïssa (2005a). Male fish blood (0 to 5 fish per concentration) was sampled in phosphate buffer supplemented with protease inhibitor and vitellogenin was quantified using a competitive ELISA (Sanchez Brion, Nilsen, \& Porcher, 2005b).

In this study, Diquat alone had no effect on hepatic oxidative stress biomarkers (figure 1) although it has been described as a redox cycling chemical. Nevertheless, it was able to alter biotransformation enzymes by inhibiting basal EROD activity and inducing GST (figure 1) in accordance with Gallagher, Buetler, Stapleton, Wang, Stahl, \& Eaton (1995) that showed an inhibition of EROD and mRNA-CYP1A production in rat in vitro and in vivo experiments. The effect on GST could be explained by its ability to protect against reactive oxygen species and its implication in oxidative metabolism of several pesticides (Halliwell \& Gutteridge, 1999) as supported by the negative correlation between EROD and GST (figure 2).

Agra190 ${ }^{\circledR}$ appeared as a strong oxidative agent as shown by induction of GPx and TBARS and depletion of total hepatic GSH pool (figure 1). These results are in accordance with the capacity of alkylphenols to alter redox status in Atlantic cod (Hasselberg, Meier, \& Svardal, 2004) and could reflect the biological membrane degradation by reactive oxygen species and the degradation product elimination by antioxidant parameters. In addition, Agral90 ${ }^{\circledR}$ inhibited almost totally basal EROD activity at low doses (figure 1). The hypothesis that this effect is related to the known capacity of nonylphenol to exert anti-CYP1A effect through its binding to the estrogen receptor (Arukwe, Forlin, \& Goksoyr, 1997) is unlikely since no effect 
on vitellogenin level in male fish was observed (figure 1). The length of NPEO alkyl group could explain the lack of vtg induction as reported by in vitro experiments (Routledge \& Sumpter, 1997). However, the weak number of male fish per group could also explain the lack of effect. Besides, EROD inhibition may rather reflect direct inhibition enzyme through either oxidative mechanism and/or membrane alteration as indicated by TBARS induction. Few data are available for NPEO effects in fish and further investigations should be done to determine the exact mechanism of NPEO adjuvants. The GST induction after NPEO exposure (figure 1) could be explained by the phenol group of NPEO making it directly available to GST (Ankley \& Agosin, 1987). Moreover, GST could have been induced by lipid peroxidation products as indicated by correlation between GST and GPx (figure 2).

Interestingly, co-exposure to the mix Diquat-Agral $90^{\circledR}$ nullified the inhibitory effects of both compounds on EROD, which could suggest that they inhibit this enzyme through distinct and antagonistic mechanisms. Conversely, the mixture led to a GST induction stronger than substances alone, suggesting a synergistic interaction. Overall, these results suggest that Diquat and Agra190 ${ }^{\circledR}$ had some interactive effects on oxidative metabolism capacity. Such possible interaction may have few consequences on oxidative stress parameters, although the mixture induced TBARS at higher levels than with Agra190 ${ }^{\circledR}$ alone.

Using the three-spined stickleback, this study shows that environmental concentrations of NPEO adjuvant generate oxidative stress and affects biotransformation enzymes in fish. Moreover, Agra190 ${ }^{\circledR}$ modulates herbicide adverse effects by increasing GST activity and lipoperoxidation. These results show that the adjuvant can exhibit more important effects than the active substance and argue for ecotoxicological risk assessment of adjuvants and tankmixes between these adjuvants and pesticides. 


\section{Acknowledgements}

This work was supported by the French Ministry of Ecology and Sustainable Development through the Programme Evaluation and Reduction of Risks due to the Use of Pesticides.

\section{References}

Ankley, G.T., \& Agosin, M. (1987). Comparative Biochemistry and Physiology B, 87, 671673.

Arukwe, A., Forlin, L., \& Goksoyr, A. (1997). Environmental Toxicology and Chemistry, 16, 2576-2583.

Gallagher, E.P., Buetler, T.M., Stapleton, P.L., Wang, C.H., Stahl, D.L., \& Eaton, D.L. (1995). Toxicology and Applied Pharmacology, 134, 81-91.

Halliwell, B., \& Gutteridge, J.M.C. (1999). Free radicals in biology and medicine. Oxford University Press.

Hasselberg, L., Meier, S., \& Svardal, A. (2004). Aquatic Toxicology, 69, 95-105.

Routledge, E.J., \& Sumpter, J.P. (1997). Journal of Biological Chemistry, 272, 3280-3288.

Sanchez, W., Palluel, O., Meunier, L., Coquery, M., Porcher, J.-M., \& Aït-Aïssa, S. (2005a). Environmental Toxicology and Pharmacology, 19, 177-183.

Sanchez, W., Brion, F., Nilsen, B.M., \& Porcher, J.-M. (2005b). $15^{\text {th }}$ annual meeting of the Society of Environmental Toxicology and Chemistry, Lille, France.

Schwaiger, J., Mallow, U., Ferling, H., Knoerr, S., Braunbeck, T., Kalbfus, W., \& Negele, R.D. (2002). Aquatic Toxicology, 59, 177-189.

Xie, L., Thrippleton, K., Irwin, M.A., Siemering, G.S., Mekebri, A., Crane, D., Berry, K., \& Schlenk, D. (2005). Toxicological Sciences, 87, 391-398. 
Figure 1. Biomarker responses after 21 days of exposure to Agral90 ${ }^{\circledR}$, Diquat and their mixture. Data are presented as mean \pm SD. T-test was performed to evaluate gender differences and data were presented separately when a significant difference was noticed (GPx). Comparison with control group were performed using two-way ANOVA followed by Sidak test . * indicates a significant difference $(\mathrm{P}<0.05)$. Numbers $1-4$ refer to the increasing concentrations of mixture.

Figure 2. Principal component analysis performed with centred and normalized hepatic biomarkers data. Exposure conditions are presented as letter-number code $(\mathrm{D}=$ Diquat, $\mathrm{A}=$ Agra190, $\mathrm{M}=$ mixture and $\mathrm{T}=$ control. The number indicates the tested concentration). 

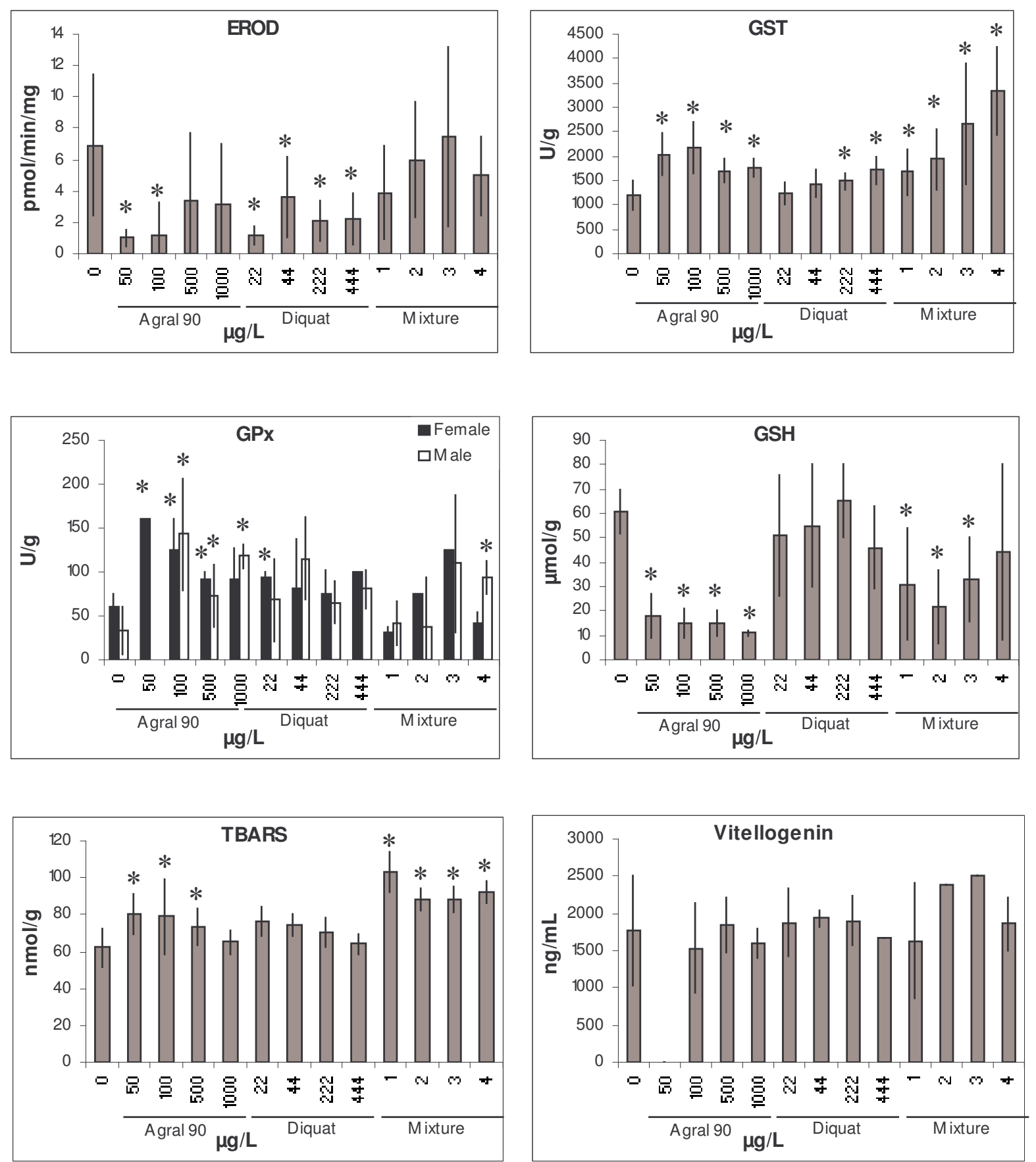

Figure 1. 


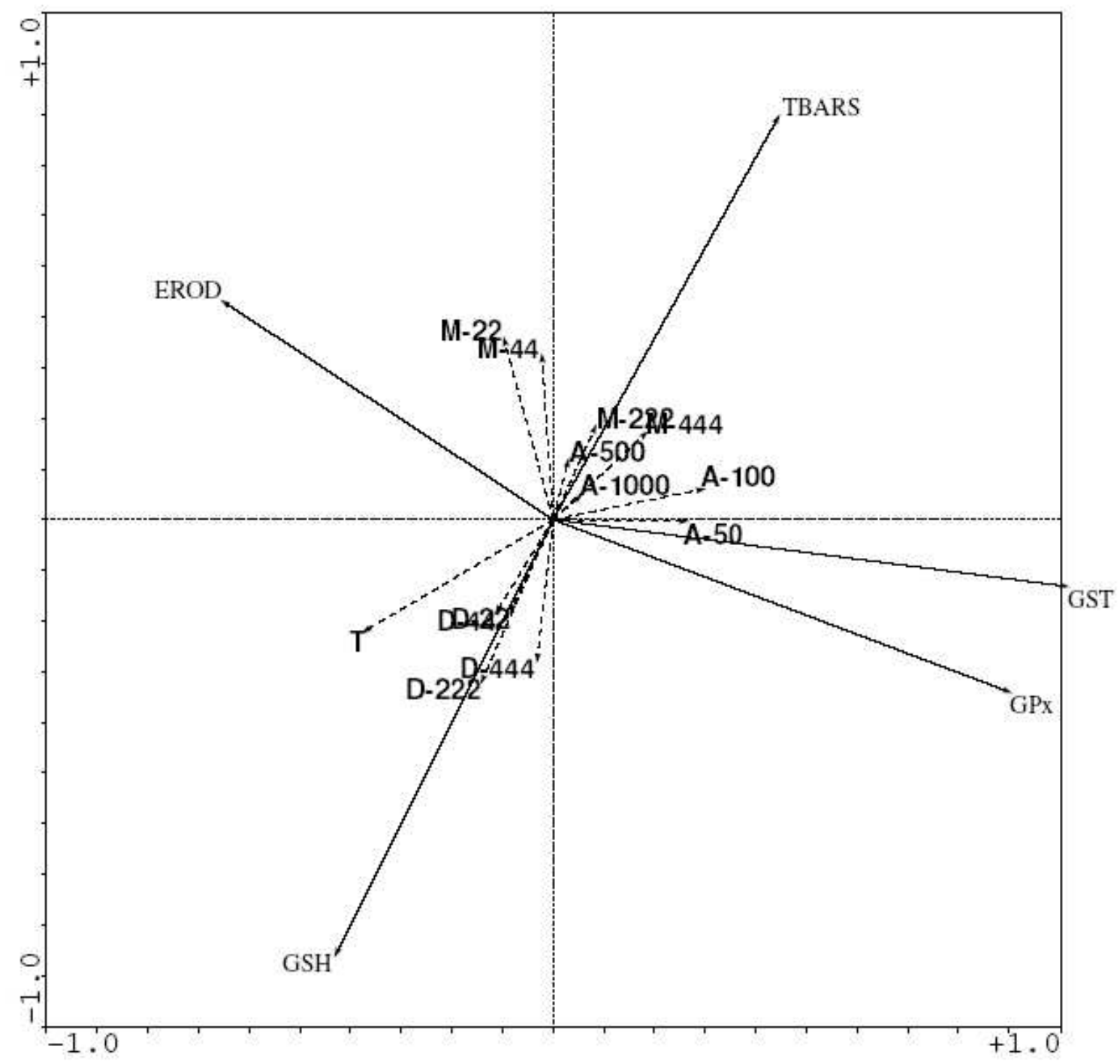

Figure 2. 